\title{
Hydrogen Sulfide Promotes Proliferation of HT-29 Colon Cancer Cells in a Mitochondria-independent Pathway
}

\author{
A. KUMARASAMY AND G. A. KURIAN* \\ Vascular Biology Lab, SASTRA Deemed University, Thanjavur-613 401, India
}

Kumarasamy et al.: Role of Hydrogen Sulphide in Colon Cancer Cells

\begin{abstract}
Several studies reported the carcinogenic and anticarcinogenic effects of hydrogen sulphide. The present study evaluated the role of mitochondria in mediating the anti/pro-carcinogenic effect of hydrogen sulphide on colon cancer cells as mitochondrial $K_{\text {ATP }}$ channel and mitochondrial electron transport chain are one of the promising targets for cancer treatment. The colon adenoma cell line and normal small intestinal epithelial cell lines were used to study the antiproliferative effect of hydrogen sulphide in the presence of enzyme inhibitors, mitochondrial $K_{\text {АTP }}$ channel modulators and in presence of inhibitors of endogenous hydrogen sulphide metabolizing enzymes namely cystathionine- $\beta$-synthase and cystathionine- $\gamma$-lyase. Antiproliferative effect of hydrogen sulphide was evaluated using 3-(4,5-dimethylthiazol-2-yl)-2,5-diphenyltetrazolium bromide, crystal violet, sulforhodamine $B$ and lactate dehydrogenase assays with its donor sodium hydrogen sulphide in both HT-29 and IEC-6 cells, where only IEC-6 cells showed significant cytotoxic effect at a concentration of $49.88 \mu \mathrm{g}\left(\mathrm{IC}_{50}\right)$ but HT-29 failed to exhibit cytotoxicity with the same hydrogen sulphide concentration. In order to identify the mitochondrial role, several electron transporting chain inhibitors and $K_{\mathrm{ATP}}$ channel modulators were used, but still hydrogen sulphide could able to enhance the colon adenoma cell line growth indicating mitochondrial in-dependency in the pro-carcinogenic effect. However, anticarcinogenic effect of hydrogen sulphide was observed only when the cells were incubated in the presence of cystathionine- $\beta$ synthase and cystathionine- $\gamma$-lyase inhibitor, indicating their influential role in determining the exogenous hydrogen sulphide toxicity in colon adenoma cell line cells.
\end{abstract}

Key words: Hydrogen sulphide, mitochondria, cystathionine- $\beta$-synthase, HT-29, IEC-6

Colorectal cancer is a heterogeneous group of disease, and is one of the leading causes of cancer related deaths in Western countries ${ }^{[1]}$. A series of genetic changes that controls specific signalling pathway involving the inactivation of tumor suppressor gene and DNA repair gene along with the activation of oncogene is responsible for the pathophysiology ${ }^{[2]}$. Survival rate statistics in developing countries showed that early detection stage of the cancer can reduce mortality rate, where the disease is highly curable, with five-year survival rates of about $90 \% 0^{[3]}$. However, many people delay seeking medical care in the early stage due to their embarrassment of symptoms related to their bowels. Moreover, the risk increases significantly after age 50 and continues to increase with age.

Although targeted therapies have slowly taken over the conventional chemotherapeutic agents, the latter still has its significance in the therapeutic regimen of colon cancer ${ }^{[4]}$. Targeted therapy with the use of inhibitors of survival pathways, along with immune cells, differentiation agents, and cytotoxic drugs to block the growth of cancer cell by interacting with specific molecules like Wnt regulators, potassium channels are promising, but limitations like resistance to the therapy due to mutations ${ }^{[5]}$ can deteriorate its efficiency. Hence, recently, therapeutic approach that utilizes targeted therapies in combination with conventional chemotherapeutic agents is found to be promising.

Advances in technology to curb cancer identified mitochondrial $\mathrm{K}_{\text {ATP }}$ channel and electron transport chain (ETC) as one of the promising targets ${ }^{[6]}$. In that aspect, hydrogen sulphide $\left(\mathrm{H}_{2} \mathrm{~S}\right)$ is used because it can modulate

This is an open access article distributed under the terms of the Creative Commons Attribution-NonCommercial-ShareAlike 3.0 License, which allows others to remix, tweak, and build upon the work non-commercially, as long as the author is credited and the new creations are licensed under the identical terms

Accepted 26 March 2019

Revised 29 November 2018

Received 14 September 2018

Indian J Pharm Sci 2019;81(3):456-463 
ETC and mitochondrial $\mathrm{K}_{\text {ATP }}$ channel effectively at lower concentrations ${ }^{[7]}$. Also, biological interest in understanding the effect of $\mathrm{H}_{2} \mathrm{~S}$ in the management of cancer pathology is gaining interest primarily due to the increased expression of $\mathrm{H}_{2} \mathrm{~S}$ synthesizing enzyme like cystathionine- $\beta$-synthase (CBS) in colon and ovarian tumor mass ${ }^{[8]}$. Few studies have shown that $\mathrm{H}_{2} \mathrm{~S}$ can promote proliferation and migration of human cancer cells (SW 480) by up regulating SIRT $1^{[9]}$, and by inhibiting nuclear factor kappa-B signalling ${ }^{[10]}$. But many other studies have demonstrated that $\mathrm{H}_{2} \mathrm{~S}$ can induce colorectal cancers $^{[11]}$, bring on hyper proliferation in human colon mucosa ${ }^{[12]}$, modulate cell cycle and cause cancer in rat intestinal epithelial cells. But the continuous exposure of $\mathrm{H}_{2} \mathrm{~S}$ to cancer cell decreased its cell survival, induce genomic DNA damage ${ }^{[13]}$ as compared to the non-cancer cells. Some of the $\mathrm{H}_{2} \mathrm{~S}$ releasing vegetables like garlic ${ }^{[14]}$, onion ${ }^{[15]}$, were also reported to have anticancer property. Thus, all the information from the above studies highlights the discrepancies in the mode of action of $\mathrm{H}_{2} \mathrm{~S}$ on colon cancer cells, which needs to be addressed.

Cancer cell metabolism primarily relies on mitochondria for its function and its dysfunction ${ }^{[16]}$ is considered to be one of the hallmarks of the cancer. In the present study, the therapeutic efficacy of $\mathrm{H}_{2} \mathrm{~S}$ in colon cancer cells, HT-29 was evaluated and compared with normal small intestinal epithelial cells, IEC-6 with a notion that $\mathrm{H}_{2} \mathrm{~S}$ can act as either carcinogen or anticancer agent. Further, the role of mitochondria in the ambiguous nature of $\mathrm{H}_{2} \mathrm{~S}$ on cancer cell was investigated by studying the cytotoxic effect in presence of ETC inhibitor, endogenous $\mathrm{H}_{2} \mathrm{~S}$ metabolic enzyme inhibitor and mitochondrial potassium channel inhibitor and opener.

\section{MATERIALS AND METHODS}

The colorectal cancer cell line, HT-29 and small intestinal epithelial cells, IEC-6, obtained from National Center for Cell Science, Pune, India, were cultured in Dulbecco's modified Eagle medium supplemented with $10 \%$ fetal calf serum, $1 \%$ antibiotics/antimycotic (completemedium) and incubated in a $5 \% \mathrm{CO}_{2}$ incubator at $37^{\circ}$. Sodium hydrosulfide (NaHS), sulforhodamine B (SRB), rotenone, diazoxide, propargyl glycine (PAG) and amino oxy acetic acid were purchased from Sigma-Aldrich (St Louis, MO, USA). Fetal calf sera, and antibiotics/antimycotics were obtained from Invitrogen; Thermo Fisher Scientific, Inc. All other reagents were purchased from HiMedia.

\section{3-(4,5-d imethylthiazol-2-yl)-2,5-diphenyl tetrazolium bromide (MTT) reduction assay:}

The MTT reduction assay protocol of Kupcsik et al. with a slight modification was used to measure cell viability by determining the level of metabolic activity, where blue formazan was formed from MTT by the action of mitochondrial dehydrogenase ${ }^{[17]}$. Briefly, the HT-29 cells were grown on a 96 well plate with a seeding density of 8000 cells/well and pretreated with various concentrations of NaHS, a donor of $\mathrm{H}_{2} \mathrm{~S}$ for $24 \mathrm{~h}$ after allowing the cells to get attached to plate and having a confluence of $75 \%$ cells. At the end of incubation, MTT $(5 \mathrm{mg} / \mathrm{ml})$ was added to each well and the formazan product was dissolved in $100 \mu 1$ of dimethyl sulfoxide after fixing the cell with paraformaldehyde. The absorbance of each well was measured at $570 \mathrm{~nm}$ using multimode reader (Biotek, synergy H1, Mumbai).

\section{Crystal violet (CV) assay:}

HT-29 cells were grown in a 96 well plate and pretreated with various concentrations of $\mathrm{NaHS}$ at their $75 \%$ confluence. The cells were then washed with phosphate-buffered saline (PBS) and fixed with $4 \%$ paraformaldehyde. The cells were then incubated with $0.5 \%$ CV (Sigma-Aldrich Corp., St. Louis, MO, USA) in $30 \%$ methanol for $10 \mathrm{~min}$ at room temperature. Excess dye was removed by washing with tap water. The cells were lysed in a $1 \%$ sodium dodecyl sulphate solution. The absorbance of the solution was measured using Biotek multimode reader at a wavelength of $570 \mathrm{~nm}^{[18]}$.

\section{SRB assay:}

SRB assay protocol as described by Vichai et al. ${ }^{[19]}$ was followed. Briefly, HT-29 cells were seeded in 96 well plate with 7000 cells/well and once it attains $75 \%$ confluency, the cells were washed with PBS and treated with NaHS of different concentrations from $5 \mu \mathrm{M}$ to $50 \mathrm{mM}$ for $24 \mathrm{~h}$. At the end of incubation, the medium was removed and washed with PBS. The cells were fixed with $10 \%$ trichloroacetic acid, stained with SRB (1\%), solubilized in $10 \mathrm{mM}$ Tris base and measured for the survival of cells using Biotek multimode reader for fluorescence at excitation of $488 \mathrm{~nm}$ and emission of $585 \mathrm{~nm}$.

\section{Lactate dehydrogenase (LDH) assay:}

The release of LDH from HT-29/IEC-6 cells was measured using a procedure as described previously ${ }^{[20]}$. 
After treating the cells with various concentrations of NaHS in a 96 well plate, the supernatant was used to measure the leaked LDH activity. The reaction was initiated by mixing the supernatant with NADH and sodium pyruvate in phosphate buffer. The change in conversion of NADH to NAD was measured at $340 \mathrm{~nm}$.

\section{Clonogenic assay:}

HT-29 cells were plated in 24 well plate at a seeding density of 40000 cells and once the cells are fixed, they were incubated with various concentrations of NaHS for $24 \mathrm{~h}$. After trypsinizing the cells, they were replated in 6 well plate at a seeding density of 20000 cells and maintained under normal growth condition for 7 to $8 \mathrm{~d}$ at $37^{\circ}$ in $\mathrm{CO}_{2}$ incubator to form colonies ${ }^{[21]}$. The colonies were measured via $\mathrm{CV}$ assay as described above.

\section{Caspase 3 activity:}

Caspase 3 activity was measured using fluorometric assay protocol as described previously ${ }^{[22]}$. After incubating the cells with NaHS, the cell lysate was prepared and incubated with $10 \mu \mathrm{l}$ of fluorogenic peptide substrate Ac-DEVD-AMC $37^{\circ}$ in the dark for $2 \mathrm{~h}$. The activation of caspase was measured using Biotek Synergy H1 multimode reader at excitation of $390 \mathrm{~nm}$ and emission of $500 \mathrm{~nm}$.

\section{Influence of ETC, $K_{\text {ATP }}$ channel and endogenous $\mathrm{H}_{2} \mathrm{~S}$ on the growth of cells in the presence of $\mathrm{H}_{2} \mathrm{~S}$ :}

To study the dependability of $\mathrm{H}_{2} \mathrm{~S}$ over the mitochondrial cellular bio-energetics, rotenone and azide were used to inhibit ETC complexes I and IV. Also, the change in mitochondria membrane permeability pore transition (MPTP), being the key regulator of apoptosis, the effects of $\mathrm{H}_{2} \mathrm{~S}$ were analysed on mitochondrial potassium ATP channel, that regulate the MPTP, by pre-treating it with a channel opener (diazoxide) and a blocker (glibenclamide). In order to distinguish the effect of exogenous and endogenous $\mathrm{H}_{2} \mathrm{~S}$, DL-PAG was used as an irreversible inhibitor of cystathionine- $\gamma$-lyase (CSE) and aminooxyacetic acid (AOA), a CBS inhibitor prior to the $\mathrm{H}_{2} \mathrm{~S}$ treatment.

\section{Statistical analysis:}

All data were presented as the mean \pm SEM for the three independent experiments. A one-way analysis of variance was performed using the prism statistical package (GraphPad Software, USA). $\mathrm{P}<0.05$ was considered statistically significant.

\section{RESULTS AND DISCUSSION}

$\mathrm{H}_{2} \mathrm{~S}$ is reported to have both procarcinogenic and anticarcinogenic effect ${ }^{[10]}$. The procarcinogenic effect was explained through the endogenous $\mathrm{H}_{2} \mathrm{~S}$ action on angiogenesis, cell cycle progression and blockade of apoptosis mechanism ${ }^{[23]}$. The anticancer effect of $\mathrm{H}_{2} \mathrm{~S}$ was explained as, at high concentration $\mathrm{H}_{2} \mathrm{~S}$ induces cell cycle arrest ${ }^{[24]}$. Advancements in cancer research identified mitochondrial $\mathrm{K}_{\text {ATP }}$ channel and ETC as one of the promising targets in the cancer treatment. Many studies have shown that cellular physiological $\mathrm{H}_{2} \mathrm{~S}$ can modulate ETC ${ }^{[25]}$ and mitochondrial $\mathrm{K}_{\text {ATP }}$ channel effectively ${ }^{[26]}$. In the present study, the critical role played by mitochondria in distinguishing the ambiguous impact of $\mathrm{H}_{2} \mathrm{~S}$ on HT-29 cells was addressed. Major findings of the study were, i) unlike in normal colon cells, $\mathrm{H}_{2} \mathrm{~S}$ promoted colon cancer cell proliferation and its action was independent of mitochondria and ii) exogenous $\mathrm{H}_{2} \mathrm{~S}$-mediated cancer cell growth depended on the level of endogenous $\mathrm{H}_{2} \mathrm{~S}$.

The toxic property of $\mathrm{H}_{2} \mathrm{~S}$ was identified around $300 \mathrm{y}$ ago and recent studies have provided enough evidences for its genotoxicity, mutagenicity and carcinogenicity ${ }^{[13,27]}$. The effects of different concentration of $\mathrm{H}_{2} \mathrm{~S}$ were examined on the cell viability of HT-29 cells for 24 h by MTT assay, CV assay, SRB assay and LDH activity (fig. 1). $\mathrm{H}_{2} \mathrm{~S}$ did not show any inhibition in their growth with different concentrations ( $5 \mu \mathrm{M}$ to $50 \mathrm{mM}$ ), except $50 \mathrm{mM}$. All cytotoxicity assays showed similar results suggesting nontoxic nature of $\mathrm{H}_{2} \mathrm{~S}$ in HT-29 colon cancer cells oncogenesis. Furthermore, the clonogenic assay (fig. 1) was carried out to assess the cell proliferative potential of $\mathrm{H}_{2} \mathrm{~S}$ and the results suggest no inhibitory action of $\mathrm{H}_{2} \mathrm{~S}$ on HT-29 cell growth. In addition, caspase 3 (an indicator of apoptosis) activity was measured at the end of the experiment and the results suggest relatively no significant increase across the different concentration, supporting the proliferative capacity of $\mathrm{H}_{2} \mathrm{~S}$ (fig. 1). Evidence from the literature supported the cell proliferative capacity of $\mathrm{H}_{2} \mathrm{~S}$ in oral cancer cells ${ }^{[28]}$, $\mathrm{C} 6$ glioma cells ${ }^{[29]}$ and human colon cancer cell ${ }^{[11]}$. Results reported by Cai et al. on HCT 116 demonstrated proliferative effects of $\mathrm{NaSH}$ up to $1 \mathrm{mM}$ without mentioning its impact on increasing concentrations further ${ }^{[11]}$, which was addressed in the present study.

Another cell line, IEC 6 was used to assess the impact of $\mathrm{NaSH}$ on the proliferative capacity. Accordingly it was found that $\mathrm{H}_{2} \mathrm{~S}$ (up to $10 \mu \mathrm{M}$ ) did not show any 

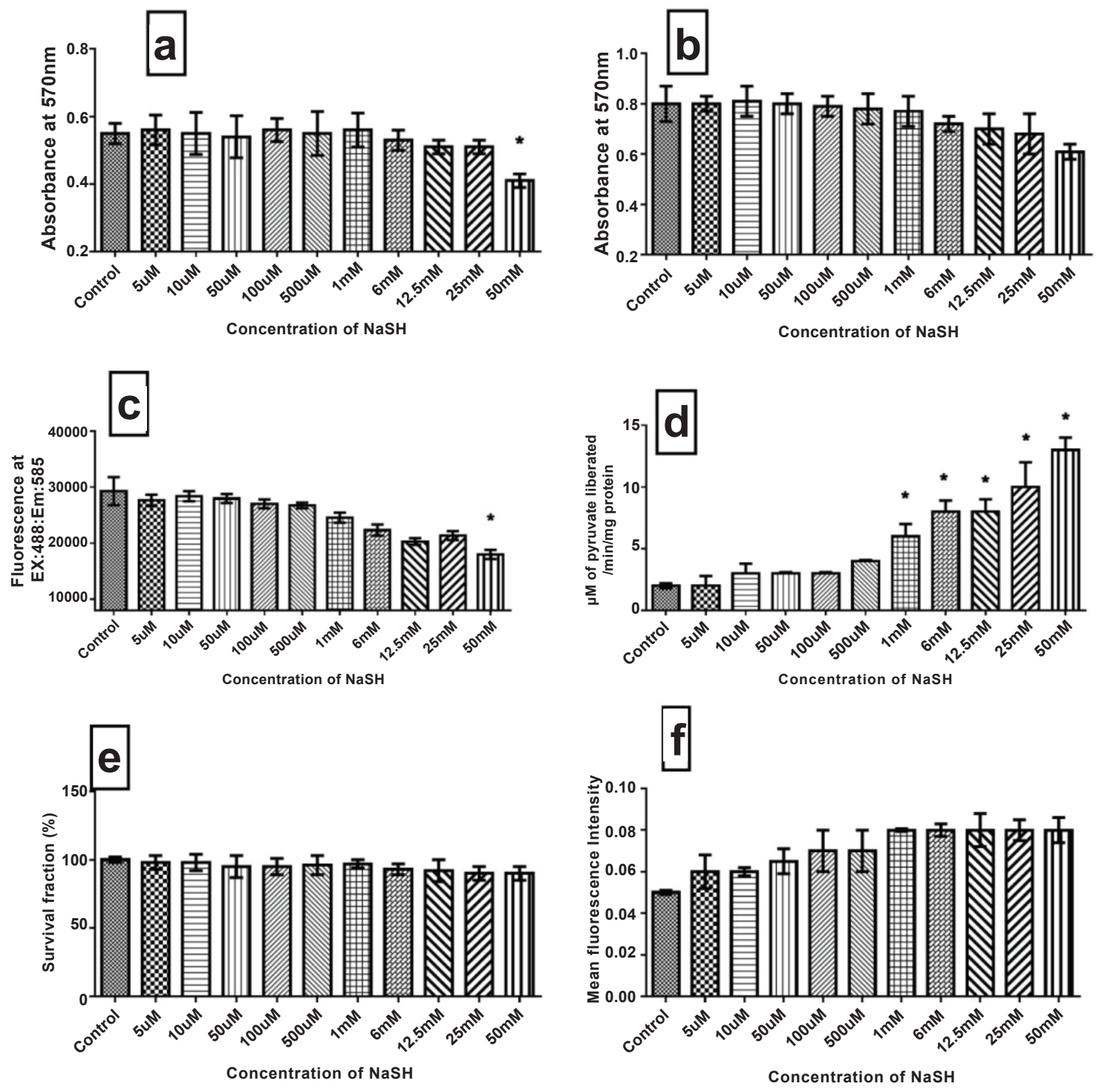

Fig. 1: Role of $\mathrm{H}_{2} \mathrm{~S}$ on the cell proliferation and apoptosis in HT-29 cells

Cytotoxic effect of $\mathrm{H}_{2} \mathrm{~S}$ on HT-29 cells evaluated by a) MTT assay; b) CV assay; c) SRB assay and d) LDH release by the cells. Cell proliferation in presence of $\mathrm{H}_{2} \mathrm{~S}$ is presented as e) clonogenic activity of $\mathrm{H}_{2} \mathrm{~S}$ in HT-29 cells. Level of apoptosis is represented in f) caspase 3 activity. Data expressed as mean \pm SD of the experiments done in triplicates. * $p<0.05$ vs. control group

significant inhibitory effect after $24 \mathrm{~h}$ exposure (fig. 2). But, above those concentrations, $\mathrm{H}_{2} \mathrm{~S}$ inhibited the IEC 6 cell viability in a dose-dependent manner measured via MTT and CV assays. SRB and LDH assay results complemented the above result. Clonogenic assay was used to reconfirm the result and it was found that clonogenic capacity was affected only after $100 \mu \mathrm{M}$ concentration (fig. 2).

The toxic effect of $\mathrm{H}_{2} \mathrm{~S}$ is well-established and different cell types experienced different toxic level depends on the expression level of its endogenous enzyme like CBS and CSE. Accordingly, it had been generalized that an intracellular concentration ranging between 0.01 to $1 \mu \mathrm{M}$ is nontoxic; instead it might trigger ATP production via electron supply to complex V.
Concentrations 3 to 30 fold higher were considered to be toxic ${ }^{[30]}$. Hence, in the present investigation whether $\mathrm{H}_{2} \mathrm{~S}$-mediated cytoprotection of HT-29 cells was dependent on mitochondrial cellular bio-energetics $\left(\mathrm{H}_{2} \mathrm{~S}\right.$ is reported to modulate mitochondria and control cellular energetics) was studied. It is well-established that the cancer cells have altered respiratory chain complex activities when compared to the normal cell, where the latter is considered to be one of the major sources of reactive oxygen species under pathological conditions. Accordingly, rotenone and azide were used to inhibit ETC complexes I and IV, respectively. The results demonstrated that rotenone and azide had a significant inhibitory effect on cell growth by 40 and $20 \%$, respectively. According to the early scientific 
reports, mitochondrial complex I and III are the major source of ROS. Hence by inhibiting complex I and III via rotenone and antimycin, respectively might generate elevated ROS production, as reported by many ${ }^{[31]}$, can kill or reduce the growth of HT-29. However, no similar effects were observed when the cells were incubated with $\mathrm{H}_{2} \mathrm{~S}$ prior to ETC inhibition. The results showed that there was no influence of these ETC enzymes over the cytoprotective effect of $\mathrm{H}_{2} \mathrm{~S}$ on HT-29 cell, measured via MTT and CV assays (fig. 3). Based on the above results, it is confirmed that cytoprotective effect of $\mathrm{H}_{2} \mathrm{~S}$ on HT-29 cancer cell was independent of ETC.

Recent strategy to combat cancer growth included those agents that can specifically compromise the structural and functional integrity of mitochondria, by modulating the respiratory chain, DNA biogenesis, potassium channels, the $\mathrm{Bcl}-2$ protein and the permeability transition pores, provided that these molecules can be selectively delivered to tumor sites ${ }^{[32]}$. $\mathrm{H}_{2} \mathrm{~S}$, being metabolized inside mitochondria can influence the MPTP transition that regulate apoptosis via mitochondrial $\mathrm{K}_{\text {ATP }}$ channel. Evading apoptosis is one of the hall marks of cancer cell ${ }^{[33]}$. The change in mitochondria MPTP is the key regulator of apoptosis and the effects of $\mathrm{H}_{2} \mathrm{~S}$ on mitochondrial potassium ATP channel was analysed, that regulate the MPTP using a channel opener, diazoxide and a channel blocker, glibenclamide. Pre-treatment of cells with diazoxide had an inhibitory effect on cell growth by $40 \%$ whereas glibenclamide had no effect on cell viability as given in fig. 4. However, cytotoxicity evaluated in HT-29 in presence of both $\mathrm{H}_{2} \mathrm{~S}$ and mitochondrial $\mathrm{K}_{\text {ATP }}$ channel modulators showed similar insignificant change when compared with the control, indicating that absence of mitochondrial dependency of $\mathrm{H}_{2} \mathrm{~S}$ in promoting the proliferation in HT-29 cells.

Evidence reported in the literature suggested that $\mathrm{H}_{2} \mathrm{~S}$ can promote cell proliferation via activating COX2/ AKT/ERK1/2 axis ${ }^{[28]}$. In another study with neuroblast cells (SH-SY5Y), it was reported that $\mathrm{H}_{2} \mathrm{~S}$ could inhibit rotenone-induced cell apoptosis via regulation of mitochondrial $\mathrm{K}_{\text {ATP }}$ channel/p38- and JNK-MAPK pathway ${ }^{[34]}$. More experimental evidence on the biological effect of $\mathrm{H}_{2} \mathrm{~S}$ suggested that in normal cells, two forms of sulphur store can release $\mathrm{H}_{2} \mathrm{~S}$ that included bound sulfane sulphur (under reducing condition) and acid labile sulphur. Exogenous administration of $\mathrm{H}_{2} \mathrm{~S}$ normally get absorbed into the cell as bound sulfane sulphur and this form can act as the source for sulphur in iron sulphur centre in ETC redox centre ${ }^{[35]}$. Szabo and associate have shown that $\mathrm{CBS}$ derived $\mathrm{H}_{2} \mathrm{~S}$ can stimulate cell proliferation, maintain bioenergetics and promote angiogenesis ${ }^{[12]}$. The endogenous gasotransmitter $\mathrm{H}_{2} \mathrm{~S}$ is generated from $\mathrm{L}$ cysteine via the action of $\mathrm{CBS}$ and $\mathrm{CSE}^{[36]}$. In order to distinguish the effect of exogenous and endogenous $\mathrm{H} 2 \mathrm{~S}, \mathrm{PAG}$ was used as an irreversible inhibitor of CSE and AOA, a CBS inhibitor. Administration of the inhibitors induced $60 \%$ reduction in cell viability as shown in fig. 5,
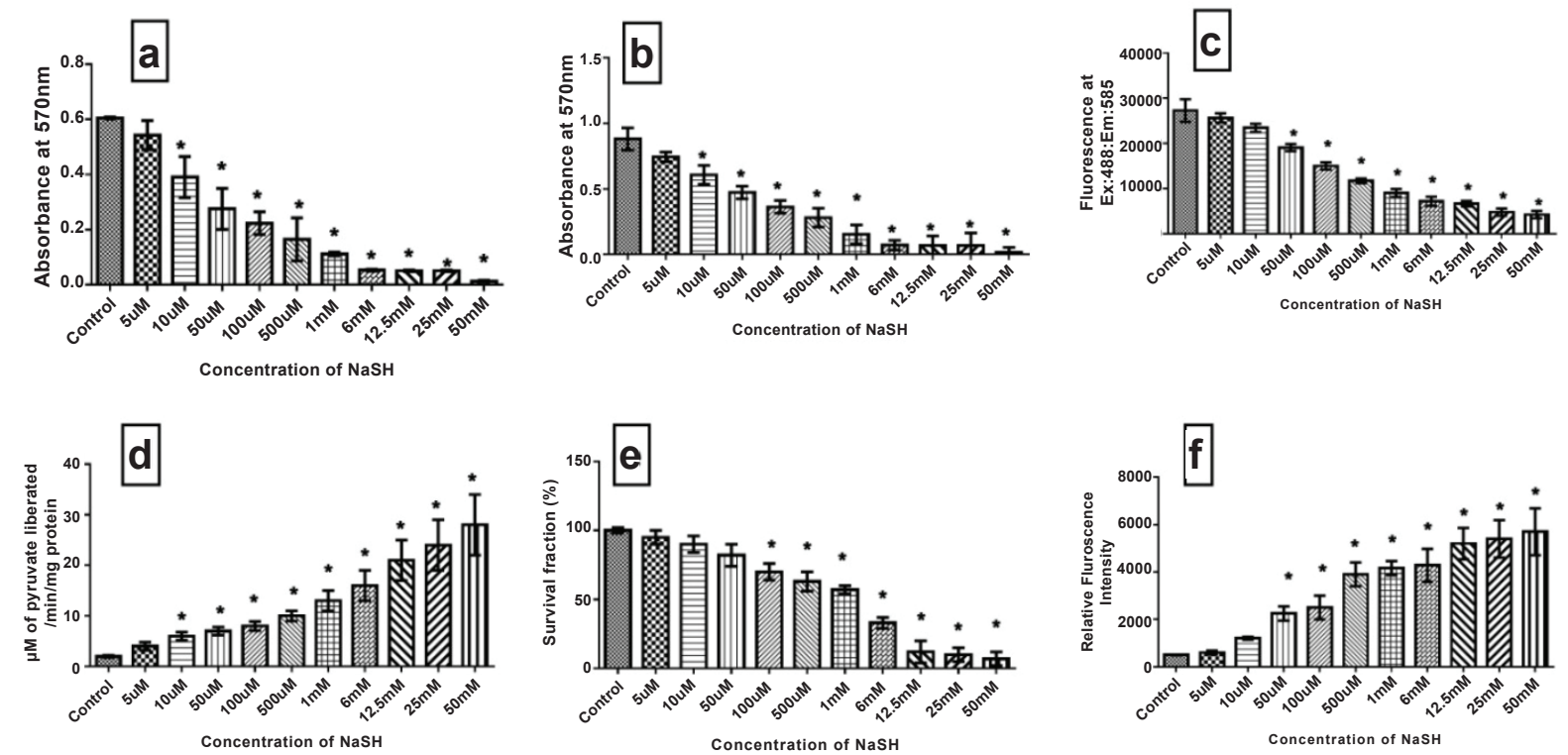

Fig. 2: Effect of $\mathrm{H}_{2} \mathrm{~S}$ on intestinal cell line, IEC-6 cells

Cell viability of IEC-6 cells when treated with $\mathrm{H}_{2} \mathrm{~S}$ is presented in a) MTT assay; b) CV assay; c) SRB assay; d) LDH release by the cells; e) cell proliferative potential of IEC-6 cells in the presence of $\mathrm{H}_{2} \mathrm{~S}$ by clonogenic assay and f) apoptosis level by caspase activity. Data expressed as mean \pm SD of the experiments done in triplicates. ${ }^{*} \mathrm{p}<0.05$ vs. control group 

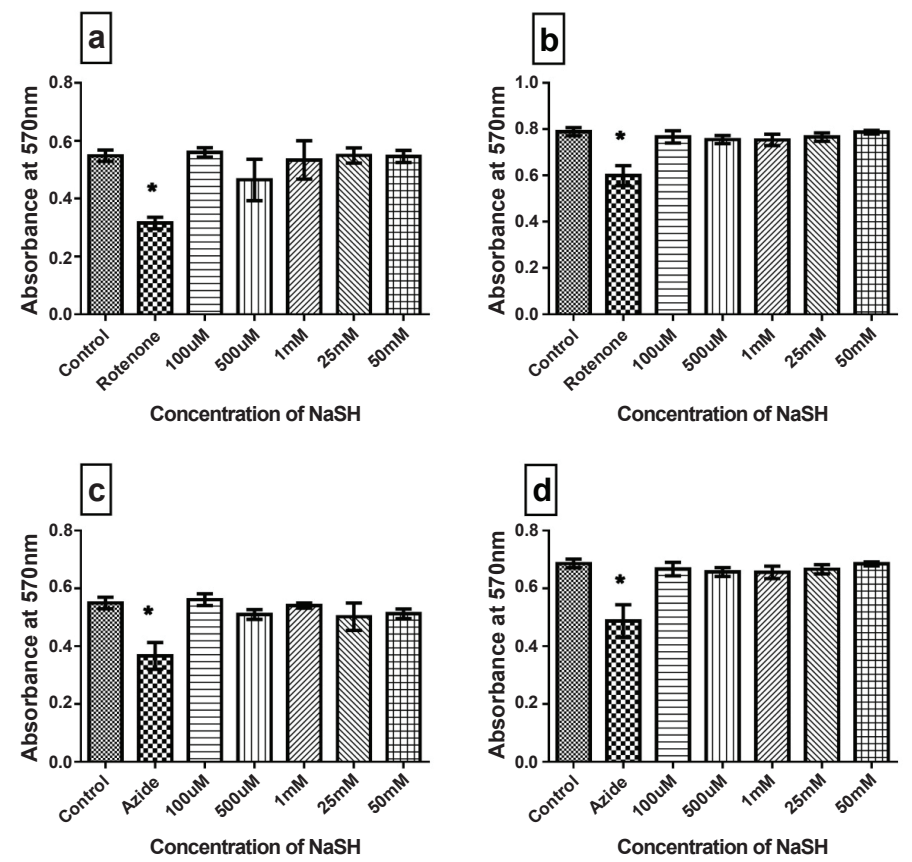

Fig. 3: Influence of ETC inhibitors on the growth of HT-29 cells in the presence of $H_{2} S$

Cell viability of HT-29 cells in the presence of $\mathrm{H}_{2} \mathrm{~S}$ when treated with electron transport chain (ETC) inhibitors I and IV are presented. a) MTT assay with pretreatment of rotenone (complex I inhibitor) and $\mathrm{H}_{2} \mathrm{~S}$; b) $\mathrm{CV}$ assay with pretreatment of rotenone (complex I inhibitor) and $\mathrm{H}_{2} \mathrm{~S}$; c) MTT assay with pretreatment of azide (complex IV inhibitor) and $\mathrm{H}_{2} \mathrm{~S}$; d) $\mathrm{CV}$ assay with pretreatment of azide (complex IV inhibitor) and $\mathrm{H}_{2} \mathrm{~S}$. Data expressed as mean \pm SD of the experiments done in triplicates. * $p<0.05$ vs. control group
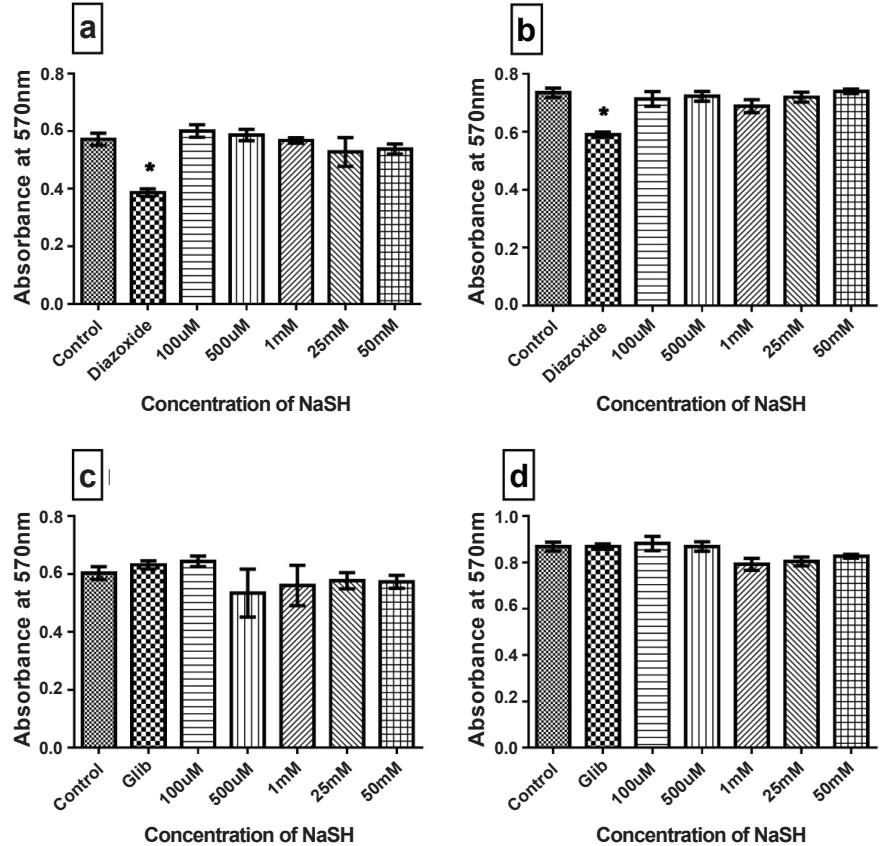

Fig. 4: Role of mitochondrial $\mathrm{K}_{\mathrm{ATP}}$ channel in the growth of $\mathrm{H}_{2} \mathrm{~S}$-treated HT-29 cells

Cell viability of HT-29 cells in the presence of $H 2 S$ when treated with a $K_{A T P}$ channel opener (diazoxide) or a $K_{A T P}$ channel closer (glibenclamide) in a) MTT assay with pretreatment of diazoxide and $\mathrm{H}_{2} \mathrm{~S} ; \mathrm{b}$ ) $\mathrm{CV}$ assay with pretreatment of diazoxide and $\mathrm{H}_{2} \mathrm{~S} ; \mathrm{c}$ ) MTT assay with pretreatment of glibenclamide and $\mathrm{H}_{2} \mathrm{~S} ;$ d) $\mathrm{CV}$ assay with pretreatment of glibenclamide and $\mathrm{H}_{2} \mathrm{~S}$. Data expressed as mean $\pm \mathrm{SD}$ of the experiments done in triplicates. * $\mathrm{p}<0.05 \mathrm{Vs}$ control group

indicating the impaired utilization of $\mathrm{H}_{2} \mathrm{~S}$ as fuel and the importance of endogenous $\mathrm{H}_{2} \mathrm{~S}$ in the cell survival. However, when the cells were pretreated with higher concentration of exogenous $\mathrm{H}_{2} \mathrm{~S}$ (above $100 \mu \mathrm{M}$ ) for
$24 \mathrm{~h}$ along with the inhibitors, the cell viability was significantly improved by $45 \%$, when compared with PAG/AOA control group. In fact, the low dose of $\mathrm{H}_{2} \mathrm{~S}$ administration along with $\mathrm{PAG} / \mathrm{AOA}$ did not improve 

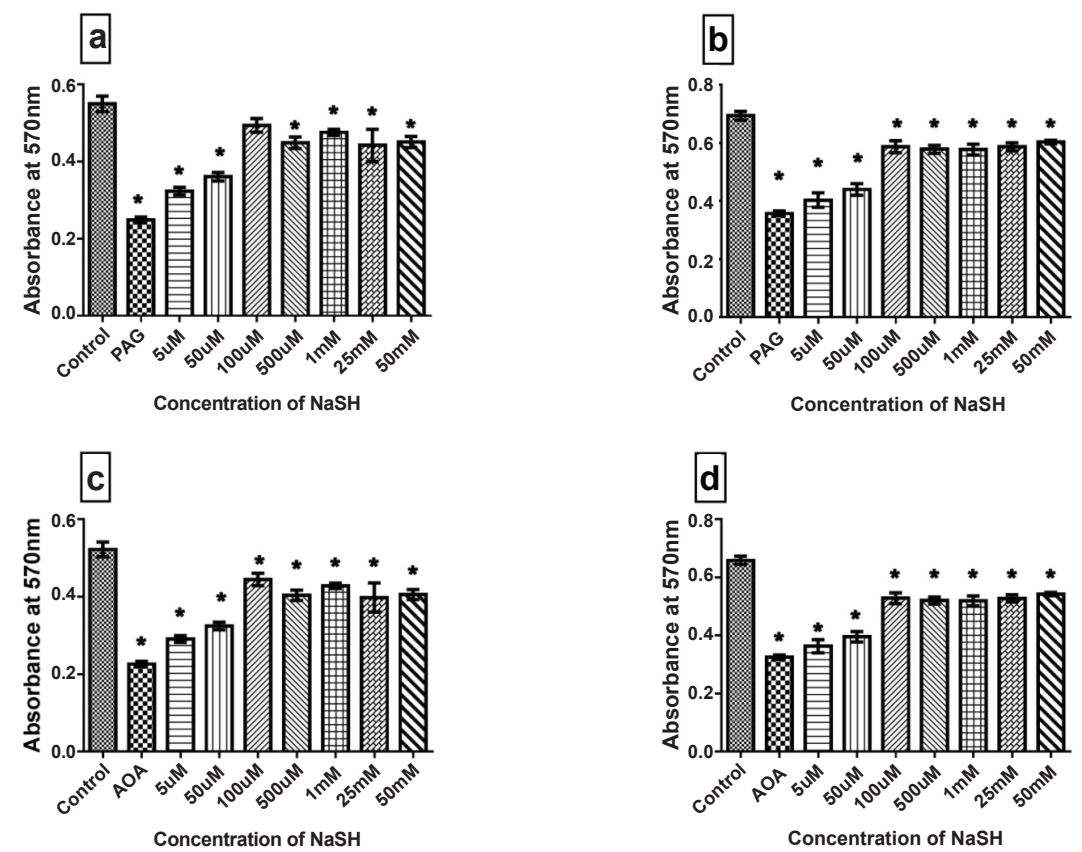

Fig. 5: Influence of endogenous $\mathrm{H}_{2} \mathrm{~S}$ on exogenous $\mathrm{H}_{2} \mathrm{~S}$-mediated cell growth in HT-29 cells

The role of endogenous $\mathrm{H}_{2} \mathrm{~S}$ on exogenous $\mathrm{H}_{2} \mathrm{~S}$-mediated cell growth of HT-29 cells was studied using a) MTT assay with pretreatment of PAG $\left(\mathrm{H}_{2} \mathrm{~S}\right.$ inhibitor) and $\left.\mathrm{H}_{2} \mathrm{~S} ; \mathrm{b}\right) \mathrm{CV}$ assay with pretreatment of PAG and $\left.\mathrm{H}_{2} \mathrm{~S} ; \mathrm{c}\right)$ MTT assay with pretreatment of AOA and $\mathrm{H}_{2} \mathrm{~S} ;$ d) $\mathrm{CV}$ assay with pretreatment of $\mathrm{AOA}$ and $\mathrm{H}_{2} \mathrm{~S}$. Data expressed as mean $\pm \mathrm{SD}$ of the experiments done in triplicates. *p $<0.05$ Vs control group

the cell viability. This emphasizes the prominent role played by endogenous $\mathrm{H}_{2} \mathrm{~S}$ in colon cancer cell growth or the endogenous $\mathrm{H}_{2} \mathrm{~S}$ enzyme regulation by exogenous $\mathrm{H}_{2} \mathrm{~S}$ administration. In this line of thought, several researchers suggest that PAG/AOA treatment to cancer cell can reduce basal cellular respiration thereby reduce ATP synthesis and attenuated the spare respiratory capacity. It is worth mentioning that $\mathrm{H}_{2} \mathrm{~S}$ mediated two opposing effects on mitochondria, i) $\mathrm{H}_{2} \mathrm{~S}$ suppressed mitochondrial function in mammalian tissue by inhibiting cytochrome c oxidase and ii) $\mathrm{H}_{2} \mathrm{~S}$ acted as an inorganic substrate and electron donor for electron transport system that generate ATP. Thus the variations in $\mathrm{H}_{2} \mathrm{~S}$ function depended on the metabolic status of the cell. Accordingly, high cell death with $\mathrm{H}_{2} \mathrm{~S}$ in presence of PAG/AOA is most likely related to the impaired utilization of $\mathrm{H}_{2} \mathrm{~S}$ as fuel or impaired transporter (malate aspartate shuttle)/transaminase reaction via pyridoxal dependent enzyme by AOA.

Based on the above observations it could be concluded that $\mathrm{H}_{2} \mathrm{~S}$ is toxic to normal colon epithelial cells above $10 \mu \mathrm{M}$ but could be well utilized by colon cancer cell even with $50 \mathrm{mM}$. The ability of HT-29 to utilize $\mathrm{H}_{2} \mathrm{~S}$ depends on the level of endogenous $\mathrm{H}_{2} \mathrm{~S}$ and independent to electron flux in ETC and change in mitochondrial $\mathrm{K}_{\mathrm{ATP}}$ channel.

\section{Acknowledgements:}

Authors wish to thank Ms. Shakila Banu for her assistance during the cell culture experiments and Ms. Sri Rahavi Boovarahan for her assistance in manuscript preparation.

\section{Conflict of interest:}

The authors declare no conflict of interest.

\section{Financial assistance:}

This study was supported by grants from the SASTRA University; Research and Modernization fund provided to the Principal Investigator Dr. Gino A. Kurian.

\section{REFERENCES}

1. Heitman SJ, Ronksley PE, Hilsden RJ, Manns BJ, Rostom A, Hemmelgarn BR. Prevalence of adenomas and colorectal cancer in average risk individuals: a systematic review and meta-analysis. Clin Gastroenterol Hepatol 2009;7(12):1272-8.

2. Ziapour P, Ataee R, Shadifar M, Vaillancourt C, Ahmadi A, Jafari-Sabet $\mathrm{M}$, et al. New intracellular and molecular aspects in pathophysiology of colorectal cancer. Gastroenterol Hepatol Bed Bench 2011;4(2):43-52.

3. Dulai PS, Sandborn WJ, Gupta S. Colorectal Cancer and Dysplasia in Inflammatory Bowel Disease: A Review of Disease Epidemiology, Pathophysiology, and Management. Cancer Prev Res 2016;9(12):887-94. 
4. Valentini AM, Armentano R, Pirrelli M, Caruso ML. Chemotherapeutic agents for colorectal cancer with a defective mismatch repair system: the state of the art. Cancer Treat Rev 2006;32(8):607-18.

5. Todaro M, Francipane MG, Medema JP, Stassi G. Colon cancer stem cells: promise of targeted therapy. Gastroenterology 2010;138(6):2151-62.

6. Leanza L, Zoratti M, Gulbins E, Szabo I. Mitochondrial ion channels as oncological targets. Oncogene 2014;33(49):5569-81.

7. Ravindran S, Ansari Banu S, Kurian GA. Hydrogen sulfide preconditioning shows differential protection towards interfibrillar and subsarcolemmal mitochondria from isolated rat heart subjected to revascularization injury. Cardiovasc Pathol 2016;25(4):306-15.

8. Bhattacharyya S, Saha S, Giri K, Lanza IR, Nair KS, Jennings $\mathrm{NB}$, et al. Cystathionine beta-synthase (CBS) contributes to advanced ovarian cancer progression and drug resistance. PLoS One 2013;8(11):e79167.

9. Hong M, Tang X, He K. Effect of hydrogen sulfide on human colon cancer SW480 cell proliferation and migration in vitro. Nan Fang Yi Ke Da Xue Xue Bao 2014;34(5):699-703.

10. Kodela R, Nath N, Chattopadhyay M, Nesbitt DE, VelazquezMartinez CA, Kashfi K. Hydrogen sulfide-releasing naproxen suppresses colon cancer cell growth and inhibits NF-kappaB signaling. Drug Des Devel Ther 2015;9:4873-82.

11. Cai WJ, Wang MJ, Ju LH, Wang C, Zhu YC. Hydrogen sulfide induces human colon cancer cell proliferation: role of Akt, ERK and p21. Cell Biol Int 2010;34(6):565-72.

12. Szabo C, Coletta C, Chao C, Modis K, Szczesny B, Papapetropoulos A, et al. Tumor-derived hydrogen sulfide, produced by cystathionine-beta-synthase, stimulates bioenergetics, cell proliferation, and angiogenesis in colon cancer. Proc Natl Acad Sci U S A 2013;110(30):12474-9.

13. Attene-Ramos MS, Wagner ED, Gaskins HR, Plewa MJ. Hydrogen sulfide induces direct radical-associated DNA damage. Mol Cancer Res 2007;5(5):455-9.

14. Tsubura A, Lai YC, Kuwata M, Uehara N, Yoshizawa K. Anticancer effects of garlic and garlic-derived compounds for breast cancer control. Anticancer Agents Med Chem 2011;11(3):249-53.

15. Zhao Y, Fan D, Zheng ZP, Li ET, Chen F, Cheng KW, et al. 8-C-(E-phenylethenyl)quercetin from onion/beef soup induces autophagic cell death in colon cancer cells through ERK activation. Mol Nutr Food Res 2017;61(2):1-10.

16. Shapovalov Y, Hoffman D, Zuch D, de Mesy Bentley KL, Eliseev RA. Mitochondrial dysfunction in cancer cells due to aberrant mitochondrial replication. J Biol Chem 2011;286(25):22331-8.

17. Kupcsik L. Estimation of cell number based on metabolic activity: the MTT reduction assay. Methods Mol Biol 2011;740:13-9.

18. Feoktistova M, Geserick P, Leverkus M. Crystal Violet Assay for Determining Viability of Cultured Cells. Cold Spring Harb Protoc 2016;2016(4):pdb.prot087379.

19. Vichai V, Kirtikara K. Sulforhodamine B colorimetric assay for cytotoxicity screening. Nat Protoc 2006;1(3):1112-6.

20. Chan FK, Moriwaki K, De Rosa MJ. Detection of necrosis by release of lactate dehydrogenase activity. Methods Mol Biol 2013;979:65-70.

21. Franken NA, Rodermond HM, Stap J, Haveman J, van Bree C. Clonogenic assay of cells in vitro. Nat Protoc 2006;1(5):23159.

22. Gorman AM, Hirt UA, Zhivotovsky B, Orrenius S, Ceccatelli S. Application of a fluorometric assay to detect caspase activity in thymus tissue undergoing apoptosis in vivo. J Immunol Methods 1999;226(1-2):43-8.

23. Wu D, Si W, Wang M, Lv S, Ji A, Li Y. Hydrogen sulfide in cancer: Friend or foe? Nitric Oxide 2015;50:38-45.

24. Takeuchi H, Setoguchi T, Machigashira M, Kanbara K, Izumi Y. Hydrogen sulfide inhibits cell proliferation and induces cell cycle arrest via an elevated p21 Cip1 level in Ca9-22 cells. J Periodontal Res 2008;43(1):90-5.

25. Szabo C, Ransy C, Modis K, Andriamihaja M, Murghes B, Coletta $\mathrm{C}$, et al. Regulation of mitochondrial bioenergetic function by hydrogen sulfide. Part I. Biochemical and physiological mechanisms. Br J Pharmacol 2014;171(8):2099122.

26. Gade AR, Kang M, Akbarali HI. Hydrogen sulfide as an allosteric modulator of ATP-sensitive potassium channels in colonic inflammation. Mol Pharmacol 2013;83(1):294-306.

27. Attene-Ramos MS, Wagner ED, Plewa MJ, Gaskins HR. Evidence that hydrogen sulfide is a genotoxic agent. Mol Cancer Res 2006;4(1):9-14.

28. Zhang S, Bian H, Li X, Wu H, Bi Q, Yan Y, et al. Hydrogen sulfide promotes cell proliferation of oral cancer through activation of the COX2/AKT/ERK1/2 axis. Oncol Rep 2016;35(5):2825-32.

29. Zhen Y, Zhang W, Liu C, He J, Lu Y, Guo R, et al. Exogenous hydrogen sulfide promotes $\mathrm{C} 6$ glioma cell growth through activation of the p38 MAPK/ERK1/2-COX-2 pathways. Oncol Rep 2015;34(5):2413-22.

30. Jiang J, Chan A, Ali S, Saha A, Haushalter KJ, Lam W-LM, et al. Hydrogen Sulfide--Mechanisms of Toxicity and Development of an Antidote. Sci Rep 2016;6:20831-31.

31. Wang L, Duan Q, Wang T, Ahmed M, Zhang N, Li Y, et al. Mitochondrial Respiratory Chain Inhibitors Involved in ROS Production Induced by Acute High Concentrations of Iodide and the Effects of SOD as a Protective Factor. Oxid Med Cell Longev 2015;2015:217670.

32. Chhabra A. Mitochondria-centric activation induced cell death of cytolytic T lymphocytes and its implications for cancer immunotherapy. Vaccine 2010;28(29):4566-72.

33. Fernald K, Kurokawa M. Evading apoptosis in cancer. Trends Cell Biol 2013;23(12):620-33.

34. Hu LF, Lu M, Wu ZY, Wong PT, Bian JS. Hydrogen sulfide inhibits rotenone-induced apoptosis via preservation of mitochondrial function. Mol Pharmacol 2009;75(1):27-34.

35. Kolluru GK, Shen X, Bir SC, Kevil CG. Hydrogen sulfide chemical biology: pathophysiological roles and detection. Nitric Oxide 2013;35:5-20.

36. Vandiver MS, Snyder SH. Hydrogen sulfide: a gasotransmitter of clinical relevance. J Mol Med 2012;90(3):255-63. 